\title{
CLIMATIC FACTORS OF ARCHITECTURE USED IN BUILDING DESIGN OF ASSOCIATION OF VISUAL ARTS OF FARS - SHIRAZ
}

\author{
Moslem Saman Ghooei \\ MA Student, Department of Architecture, Islamic Azad University, International Qeshm Branch, \\ Qeshm, Iran \\ Alireza Shojaei \\ Assistant Professor, Department of Architecture, Islamic Azadniversity, International Qeshm Branch, \\ Qeshm, Iran
}

\begin{abstract}
The objective of the present study was to investigate the climatic factors of architecture used in building design of Association of Visual Arts of Fars - Shiraz. Methods: In the present study, descriptive - libraries and descriptive - analytic method was used. Results: By investigating the different climatic factors and geographical location of the city of Shiraz and also the investigating the impact of climatic conditions on the formation of other buildings, the climatic factors of architecture used in building design of Association of Visual Arts of Shiraz was more pronounced. In designing listed building from climatic conditions of region to improve the life and well-considered energy consumption is also improved. Another feature that has been considered in the design and construction are as follows. Considering the above and visit the city map, the site with an area of 7000 square meters in the neighborhood of Hafeziyeh with a vision to the historic fabric of the city is located. Piece of land of the historic fabric of the city of Shiraz between two Adabiyat and Haft Tan streets which is located in the North East of Shiraz, this site is located on the back of Hafeziyeh with a slope of about 5 percent. This site is to the north overlooking Haft Tan and Jahan Nama Garden and the south side is overlooking Hafeziyeh.
\end{abstract}

Keyword: City of Shiraz, Shiraz climatic conditions, Architecture of Association of Visual Arts

\section{INTRODUCTION}

The culture of a society is unique and involves a combination of values and norms that cannot be found elsewhere. A diverse range of cultures so widespread that even the understanding of mental construction lifestyle of our ancestors in our society is relatively difficult. (Toufan, 2007) However, any country that has a history and civilization is clear that this culture will be richer culture as well as the identity. Thus the Arts as one of the sub-culture of each country or region can be considered as one of the indicators of cultural and national identity and the civilization it represents the country because one of the purposes of art, especially architecture as one of the seven arts, culture and identity over the centuries in countries. Culture is an important factor in the formation of architectural spaces is considered. Every society has its own culture which is the foundation of society, founded the architecture and architecture of the Community objective picture of the cultural heritage. In fact, architecture and culture of a nation is measured by the real. The culture of the community is the formation of spaces. (Diba, 1999). Iran's territorial extent latitudes, varied climates and has been followed. In the meantime, the concept of architecture is influenced by a variety of ancient and diverse architecture tailored to each region, by the people of this land has emerged. From the start, I realized that human experience in any environment How to build a building to have the most favorable housing. As long as man is free to determine its location must all interactions with the environment in mind. This mechanism is to estimate the chances environmental engineers and architects often considered as a fact in the history of architecture and building design, attempt to respond to weather conditions, even in so-called primitive architectural design and magnificent climate has been precisely (Watson, 2011). Given the importance of climate's influence on the design of the building, one of the buildings in the city of Shiraz in terms of climate features intended to make the design and architecture was studied. The importance of choosing the foundation of Association of 
Visual Arts of Shiraz, due to the lack of relevant research can be noted in the description of its architectural features.

\section{OBJECTIVE}

The objective of the present study was to investigate the climatic factors of architecture used in building design of Association of Visual Arts of Fars - Shiraz.

\section{RESEARCH METHODOLOGY}

$\mathrm{n}$ the present study, descriptive - libraries and descriptive - analytic method was used.

\section{DISCUSSION AND CONCLUSION}

\section{INVESTIGATING THE STATUS OF SHIRAZ CITY}

Shiraz city, Capital of Fars Province in longitude 52 degrees, latitude 29 degrees 32 minutes and in an area with a height of 1491 meters above sea level is located. Shiraz city with an area of 10531 square kilometers, $8.5 \%$ of the total area of Fars province to be allocated. This city from North is limited to the city of Marvdasht and Arsanjan and from West is limited to the city of Mamasani and Kazeroon, from the south is limited to the city of Firozabad and Jahrom and from the East is limited to the city of Fasa and Neyriz. According to the latest national distribution urban areas of the city has seven points (Shiraz, Kovar, Sarvestan, Kharameh, Zarghan, Daryan, Lapouei) and six sections namely (Zarghan, Savestan, Karbal, Markazi, Arjan and Kovar) and 22 villages and 515 villages with a population of 216 villages have been deserted (Kasmaee, 2010)).

\section{COMFORT ZONE}

By using different Givoni building bioclimatic tables and control of interior spaces in climatic conditions of region is investigated. Human comfort zone in relation to two climate, temperature and air humidity and temperature parameters based on dry, wet temperature, relative humidity and vapor pressure specified. As is clear from Table bioclimatic building, May in comfort zone has favorable conditions. In the months of August, July and June there is a lack of moisture. October, November, February and March using enough radiation to appear. But in December, January and February to achieve comfort, additional heat source is necessary.

\section{DETERMINING THE OPTIMUM DIRECTION USING CLIMATIC DESIGN}

To determine an optimal direction for buildings and sets, two main operating position of the sun (radiation) and local prevailing winds and have been studied. Accordingly, the amount of thermal energy thermal energy that falls on vertical surfaces in latitude 29 degrees has been calculated and plotted. Change heating curve shows the energy balance in different directions building is warm and cold periods. According to the desired direction, the highest in winter and lowest in summer insolation is received. South direction is selected as the optimum direction. The wind directions from West to the North West domain is not desirable shifts. In addition, East and Southwest is the dominant local winds. To the south is optimal in terms of radiation that is effective on the winds. Because the cold winter winds northwest 50 to 60 percent decrease. Local wind in the summer and warm seasons desired effects, especially mountain - Western - Southwest winds is noticeable and effective in the modulation of comfort. To determine the relative importance of the different climatic design, especially in climates multiple table's month has suggested that using them in possession of statistics major regional climate characteristics and resistance to climatic conditions in the study area can be detected as below. Thermal conditions in this region in the whole year so that should be indoors to keep warm at night, the heat-generating devices are used, but the average maximum temperature and minimum relative humidity in this region in the whole year within the system passive solar is located. So for space heating in the building during the winter and even during the coldest month of solar energy can be used. In the hottest months of the year, the hottest hours of air thermal conditions outside the scope of building materials and the use of cooling devices placed. However, due to dry in a substantial part of the day will be using the thermal performance of building materials and heavy thermal conditions indoors to be controlled at an acceptable level.

\section{INVESTIGATION OF CLIMATE ISSUES ASSOCIATED WITH BUILDING ARCHITECTURE}


General tissue Shiraz has a rotating 30 degrees to the West, which determines the order buildings to 30 degrees west or $60^{\circ}$ southeast. The determining factor in the rotation direction of the sun into the shade as well as a range of external spaces.

\section{CLIMATIC ARCHITECTURE:}

Architecture is different climates with different applications in each of its elements must be deployed comfort to relax (Kasmaee, 2003, page 11) Hence creating a comfortable environment and favorable conditions for life and security of the residents against adverse environmental conditions and serious architecture is an integral principles that according to each region in proportion to its review of the work and patterns provided.

\section{CLIMATE OF SHIRAZ:}

According to studies in the city's annual average climatic factors is as follows. The average temperature in Shiraz 17.24 on an annual basis, total rainfall 322.2, the average relative humidity 41.8 and the number of frost days is 50 days a year.

\begin{tabular}{|c|c|c|c|c|c}
\hline $\begin{array}{c}\text { (Direction) prevailing } \\
\text { winds }\end{array}$ & Frost days & $\begin{array}{c}\text { Relative } \\
\text { Humidity } \\
\text { (percent) }\end{array}$ & Temperature & $\begin{array}{c}\text { Precipitation } \\
\text { (mm) }\end{array}$ & \\
\hline West and North West & 50 & 41.8 & 17.24 & 322.2 & $\begin{array}{c}\text { Annual } \\
\text { average }\end{array}$ \\
\hline
\end{tabular}

\section{BIOCLIMATIC CHARTS (BASED ON COMFORT ZONE OF SHIRAZ):}

According to the bioclimatic certain that elements in the city due to climate conditions in May and June and September to provide comfort and convenience. In July and August under conditions of low humidity and high evaporation temperature and relative humidity range, and just in case the wind blowing in this area, providing comfort conditions even in the shade. In the cold months (about 2 or 3 months) for adjusting the temperature of the heat source must be used or the use of solar heat and solar system was disabled.

\section{Building Environment - Climatic Table Shiraz}

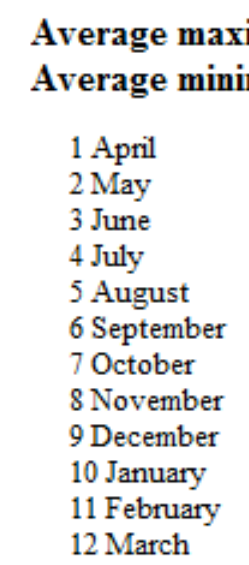

(Kasmaee climate and architecture 1999 - Article of Climatic Survey of Shiraz City - Mr. Hamed Ayali - Master of Architecture - Islamic Azad University of Shiraz Branch) 
ntroduction of available and effective monuments in the range of design

1- Hafeziyeh: Adjacent to the site is located in the southwestern part of the architecture and its totality in terms of architectural form and etc. has had an impact.

2- $\quad$ Library and the National Archives: In the western part of the National Library and Archives is located in the vicinity of the project site is part of a series on the topic of identity and neighborhood perspective is effective.

3- Jahan Nama Garden: Jahan Nama Garden is one of the oldest gardens in Shiraz and is near the tomb of Hafiz and it is an octagonal building, there are also two long street in the North and South and East and West Garden for access to the project site is under investigation.

4- $\quad$ There are also complexes such as the Faculty of Literature and Hafiz Hall Cultural Complex that help its identity.

\section{NATURAL FEATURES OF SITE}

Alive nature, low noise pollution and being in the context of a historical center - cultural education and is eventually need to be a cultural center in this complex of the reasons for this complex in this area. Other reasons for choosing this site without being a place for education and culture of ethnic minorities and the rest of the series in television history that can increase the effects of this center. In addition, a map of the site users also predicted a cultural and art center. The placement of such sites and benefit from sunlight at all during the year.

\section{RESULT}

By investigating the different climatic factors and geographical location of the city of Shiraz and also the investigating the impact of climatic conditions on the formation of other buildings, the climatic factors of architecture used in building design of Association of Visual Arts of Shiraz was more pronounced. In designing listed building from climatic conditions of region to improve the life and well-considered energy consumption is also improved. Another feature that has been considered in the design and construction are as follows.

Considering the above and visit the city map, the site with an area of 7000 square meters in the neighborhood of Hafeziyeh with a vision to the historic fabric of the city is located. Piece of land of the historic fabric of the city of Shiraz between two Adabiyat and Haft Tan streets which is located in the North East of Shiraz, this site is located on the back of Hafeziyeh with a slope of about 5 percent. This site is to the north overlooking Haft Tan and Jahan Nama Garden and the south side is overlooking Hafeziyeh. The East is complex is in the vicinity of the University Literature and the West of it Hafiz Hall and National Library are located.

\section{REFERENCES}

Daryoush, Babak., 2012, humans, nature and architecture, Tehran, Third Edition, Science and Knowledge Publications.

Razjooyan, Mahmoud, 1988, comfort by architectural harmony with the climate, Tehran, martyr Beheshti University.

Rahnamaei, Mohammad Taghi, 2004, the process of urban planning, Tehran, printing, Samt Publications.

Management and Planning Organization, 1996, the province statistics, Statistical Yearbook of the country.

Shaterian, Reza., 2009, climate and architecture, Tehran, Second Edition, Simaye Danesh Publications.

Tavoussi, Taghi., 2008, climate and modernization of schools of architecture of Isfahan, geography and development No. 11.

Falmaki, Mansour., 2005, Siri urban experiences from Venice to Shiraz, Tehran, Faza Publication. 
Ghobadian, Vahid., 2011, investigating the climate in traditional buildings, Tehran, Tehran University Press.

Kaviani, Mohammad Reza, 1993, identification and mapping of the human bioclimatic Iran, Geographical Research Quarterly, Issue 28.

Kasmaee, Morteza., 1993, Iran climatic zoning, housing and residential environment, Building and Housing Research Center, First Edition.

Razjooyan, Mahmoud, (2009) comfort in the shelter of architecture in harmony with the climate, martyr Beheshti University, Tehran.

Moradi, Sasan. (2007) set the environmental conditions, Shahidi Publications. Tavassoli, Mahmoud (2002) in the arid climate of city building and architecture, N, Payam. Dr. Hekmati, Jamshid. (2007) landscape engineering, Tehran Sepehr Publication. Architects' Data, O, P, translated by: Hossein Mozaffari Torshizi, Third Edition, Summer 2003, architecture information, Azadeh Publications, pp. 333, 334.

Jahedian, Sasan., 2004 - 2005, Museum of Fine Arts Thesis (Architecture), Shiraz Islamic Azad University, School of Architecture.

Marzban, P. 1999, "roots pulled from the soil", Tavous, No. 1.

Edmund Burke Feldman, translated by Parviz Marzban, first published in 1999, a variety of visual experiences, Soroush Publications, tenth to the fourteenth season. 